\title{
Nピyクス 全身性エリテマトーデス：診断と治療の進歩
}

\section{II. 治療 \\ 5. 特殊な病態の臨床と治療 \\ 2）中枢神経ループス}

柏崎 禎夫* 岡田 純** 石川 章**

はじめに

全身性エリテマトーデス（SLE）では，神経系 は皮䖉, 関節, 腎臟と並んで主要な標的㵴器であ る。中枢神経 (CNS), 脊髄, 末梢神経のすべてが 障害されるが，克の中でも中枢神経ループス (CNS-SLE) が，出現頻度が高く，かつ予啳に及 ぼす影響が大であることから，SLE患者の診療上 その認識は不可久である.

本稿では, 自験成績を混じえて, CNS-SLEの臨 床と治療について概説する。

\section{1. 頻度と生存率}

SLEに括けるCNS-SLEの出現頻度は文献上 25 から75\%(自験例65/223=29\%)，その5ち神経症 状は $11 〜 75 \%(17 \%) ，$ 精神症状は17－59\%(12\%) と施設間でかなりの差がみられるが，それは対象 患者の相違によるだけではなく，研究者間での CNS-SLEに対する考光方に差異があることを反 映しているものと推测される。

SLEの生存率は20年前と比べて驚異的に延び

*かしわさきさだ技，東京女子医科大学りウマチ 痛風七ンタ一

**扔かた じ虾ん，**いしかわ古きら, 北里大学 医学部内科
ているが，中权神経障害が依然として腎障害に次 ぐ主な死因の一つであることは今も变わってはい ない.CNS-SLEのlife table methodによる5 年生 存率はEstesらの報告では55\%, Leeらの報告では $82 \%$ ，全症例のそ机（おの打の76.9，91\%）と 比較すると低い，自験成績でも1979年度集計では 65\%と低かったものが，1989年度集計では85\%と 上昇して扣り，軽症例の増加の灭ならず，治療法 の進歩も5かがえる. 神経症状(痉孪を除く）を 呈するものは精神症状を呈するものより，また精 神症状の中でも器質的精神症状は機能的精神症状 より予後が悪い，最近ではCNS-SLE症例には大 量のステロイド薬を投与する傾向があるため, 重 症感染症の合併例が多くなり, 感染症がCNS. SLEでも直接死因としての比重が大きくなった。

\section{2. 臨床症状}

CNS-SLEはその種類・程度共に神経梅毒に比 肩されるように、ありとあらゆる症状がみられる のが特徵ではあるが，何一つとして疾病特異的な ものはない(表 1)。頻度の高いものが精神症状, 脳血管障害と㾏孪である。頭痛もかなり高い頻度 で観察される。まれなものとして，䯣膜炎・䯣膜 脳炎, 脳神経障害, 舞踏病, 片側ハリスムスや振 戦などの不随意運動もみられる。精神症状，脳血 
表 1．自験SLE 223例にみられた中权神経症状とその 出現時年令

\begin{tabular}{l|cc|c}
\hline & 例 & 数 & $\begin{array}{c}\text { 中枢神経症状 } \\
\text { 出現時平均年令 }\end{array}$ \\
\hline 精神症状 & 27 & $41.8 \%$ & $38.2 \pm 7.3$ \\
脳血管障害 & 19 & 25.5 & $38.2 \pm 7.3$ \\
痉孪 & 15 & 23.1 & $32.5 \pm 11.9$ \\
随膜脳咨 & 4 & 6.1 & $25.7 \pm 8.5$ \\
髄膜炎 & 3 & 4.7 & $27.9 \pm 10.0$ \\
舞踏病 & 2 & 3.1 & $40.0 \pm 10.0$ \\
\hline
\end{tabular}

管障害は中年に, 髄膜炎・䯣膜脳炎は比較的若年 者に発症する傾向がある。

\section{1）精神症状}

精神症状も様々なるのが出現するため，SLE以 外の原因によるものとの鑑別が日常診療上しばし ば問題になる。そのためSLEの精神症状に対して 種々の分類が試みられてきたが，最近では大きく 器質的なものと機能的なものの 2 群に分類して扱 う傾向が多い。

その区別は見当識，判断，記憶，知覚などの認 知機能障害の存在の有無によっている。すなわち, その表現型は前者では意識障害およびままたは痴 呆であるのに対して，後者ではうつ状態や不安な どの心囚反応あるいは分裂病様状態などの内因性 反応である。

精神症状を 2 群に分ける臨床的必要性は，両群 で臨床経過，予後および治療法が異なることにあ る。典型的な場合には器質的精神病の発症は急性 で，電撃性ですらある。一過性で完全に回復する ことが多いが，中には不可逆性で慢性進行性の痴 呆になり最後は死の転帰をとるものもあり，機能 的精神病に比べて予後は悪い，多くは神経症状を 合併している。

それに対して機能的精神病の発病の仕方は緩徐 で，神経症状を伴わず，一般に予後は良い，その ため, 他の慢性疾患に伴う心因性反応と区別でき ないことが多い。しかし，SLEでは極端ならつ状 態に陥ることもあり，かかる場合には全く内向的 かつ，寡黙状態になり，自殺行為に走る危険性子 ある。

治療については前者にはステロイド薬の増量が
効を奏するが，後者には抗精神薬の併用が適用と なる。しかし，両者を劃然と区別できない症例も あれば，両者が混在している症例もある。とくに 極端なうつ状態では器質的精神病は隠斐されてし まうため，その診断は困難である。かかる場合に はretrospectiveに判断するしか力法はない，一般 にSLEの精神症状は，進行性痴呆の型をとるもの を除き可逆性で， 6 力月以上持続することはまれ であり，多くは6 週間以内に軽快する。

\section{2）神経症状}

㾏挛は最もよくみられる神経症状である。しば しば他の精神・神経症状を伴わないで単独で出現 するが，かかる場合は予後は良い，最もよくみら れる型は大発作であるが，交れに小発作，Jackson 型，焦点型，側頭葉型も双られる。てんかん重積 状態に陥る場合は一般に予後不良の兆である。

頭痛は恐らくSLEでもっともよく遭遇する中 权神経症状と考兵るが，それに関する詳細な研究 は少ない，它の性状は激烈で再発を繰り返す型む 西れば，片頭痛様のこともある．SLEの活動性の 消長と並行して出没し，酒石酸エルゴタミンなど の片頭痛の特効薬よりステロイド薬の方が奏効 し, 閃輝暗点を伴う典型的片頭痛や普通型片頭痛 を呈した症例も報告されている。今後は本症に伴 ら頭痛にもっと関心を払らべきであるう。

脳神経障害もCNS-SLEの $5 \sim 33 \%$ に認めら れ，核性と核下性麻疩のものが観察される。脳神 経障害は通常前駆症状を伴わず，㔖然発症するこ とが多い。同名半盲，失明，乳頭浮畽，外眼笳麻 瘏などが最も多い，網膜病変も頻度が高く，臨床 的に綿花状白斑として9－24\%の症例で認められ る。網膜剥離，視神経萎縮や失明はステロイド薬 の治療への導入以後まれになった。

舞踏病は極めてまれな症状であるが，時に初発 症状として出現する。ささらには，SLEの診断より 数年先行してみられた報告もあり，リウマチ熱 (RF)との鑑別上注意を要する.SLEでの舞踏病は 一過性のこともあれば，再発を繰り返すものや2 年以上持続するものもあり，経過は症例によって まちまちである。

従来，SLEの中枢神経障害は途発症状とされて 
いたが，その出現はSLEの経過中いずれの時期に 子みられ，その認識を变克る必要がある。自験例 では中枢神程障害は $78.6 \%$ 症例は診断確定後 1 年以内に発症し，初発あるいは早期症状と考えら れた症例も少なくなかった。

\section{3）他の臟器症状との関連}

中枢神経障害を呈するSLEの症例は一般に症 状が多彩である傾向があるが，特定の蔵器障害々 の間の関連性，すな放ち，CNS-SLEは特別の病像 を形成しているか否かはまだ未解決であるが，大 切な研究課題である。をの重要性の一つはい京た 不明のCNS-SLEの病態を解析していく上に，臨 床面からも何らかの手䀣りを引き出せる可能性が あるからである。

中枢神経障害之血管炎および血小板減少症との 間に有意の相関があるとする報告もある。私共も 中枢神経障害，上くに中枢神経障害と血管炎を反 映すると考克られる皮留梗塞症状招よび末梢神経 障害との間に有意の相関が存在する成績を得てい る。剖検上脳内に明らかな血管炎が証明されてい ることは極めてまれであることは事実であるが，

Johnsonらの詳細な病理学的研究成績と同様に上 述の臨床成績はCNS-SLEの病態微小血管を含 めた血管障害の立場から再検討する必要性を示唆 している.

自験例でのCNS-SLEの病型別臨床的特徵は, 精神症状群では脱毛, 痉挛群では皮学梗塞・脱毛, 膸膜脳炎群では蝶形紅斑・皮䖉梗塞症状・脱毛が有 意に多く見られ，脳血管障害群では重篤な腎障害 の出現頻度が少ない傾向がみられた（表 2 )。

\section{3. 発症機序}

中权神経障害の発症機序は依然としてべールに つつま机たままであるが，SLEが代表的な全身性 自己免疫疾患であることから，最近でも免疫学的 機序を想定寸る説が支配的で，それも循環免疫複 合物によるもの上神経細胞膜に対する抗体による るのとに大別される。

前者の主な根拠として，(1)腎症の有無に拘らず， CNS-SLEの活動期に血清中のDNA抗体洒が高く 血清補体価は低下寸ること, (2)䯣液中のDNA抗体 価の上昇, 補体第 4 成分の低下およびDNA-DNA 抗体複合物の証明, (3)CNS-SLEで形態学的にも 機能的にも系球体基底膜と極めて類似性のある choroid plexusに免疫複合物の沈着が証明される こと, (4)急性の血清病を起こさせたウサギや hybrid (NZBxW) $F_{1}$ マウスのchoroid plexusk 免疫複合物が沈着していたことなど，が挙げられ る.しかし，CNS-SLEと血清並ひに蹎液中のDNA 抗体価や補体価との相関については疑問視する成 績も発表されており，京だ結論は出ていない，

つぎに，神経細胞膜自体の抗体ではないが，乙 れと交叉反応をするといら点で近年注目を集めた のが抗リンハ球抗体である.SLE患者血清中には 抗リンパ球抗体が高率に㛟出されること，マウス のみならずヒトでもリンパ球と中枢神経組織との 間には共通抗原が存在すること，上トの多発性硬 化症や時に脳资の発症を及る麻疹，風疹，伝染性 単核症などのウイルス感染時にも抗りンハ球抗体 が出現すること，さらにはSLEの中枢神経障害と

表 2、中枢神経ループスの病型別臨床症状

\begin{tabular}{|c|c|c|c|c|c|}
\hline & 蝶形紅斑 & 皮薄梗塞 & 脱 毛 & 腎 症 & 腎不全 \\
\hline 精神症状 & $51.8 \%$ & $22.2 \%$ & $48.1 \% *$ & $70.3 \%$ & 18.5 \\
\hline 脳血管障害 & 50.0 & 14.0 & 42.8 & 57.1 & 0.0 \\
\hline 㾏挛 & 60.0 & $40.0^{*}$ & $46.7^{*}$ & 66.7 & 20.0 \\
\hline 髓膜脳炎 & $100 *$ & $75.0^{*}$ & $50.0^{*}$ & 75.0 & 0.0 \\
\hline 䯙膜炎 & 66.7 & 0.0 & 33.3 & 50.0 & 0.0 \\
\hline 舞踏病 & 100 & 0.0 & 50.0 & 50.0 & 0.0 \\
\hline その他のループス & 45.2 & 11.0 & 28.6 & 51.3 & 13.0 \\
\hline
\end{tabular}

${ }^{*} \mathrm{p}<0.05$ 
抗リンハ球抗体の有無るるいは抗体価との間に相 関が文られるといら成績などから，SLEの中枢神 経障害の発症に抗り义, 球抗体加関与寸正可能性

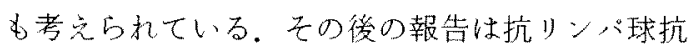
体上中枢神経障㕩の発症との間に相関が少られな いとするものが多いことやSLEでは抗りンバ球 抗体がSLEにbつく中枢神経障害の発症頻度 以上に高率に陽性である点で抗リンパ球抗体を SLEの中枢神経障害の一因とするにはまだ多く の疑問が残されている。

それに対して, SLEの抗リンパ球抗体には脳抗 原の反応性で少なくとも二つのsubpopulationに 分けられ，CNS-SLEの抗リン八球抗体は脳抗原 で吸収されるが, non CNS-SLEのそれは吸収され ないといら與味ある成績が発表された。すなわち， CNS-SLEの発症に与かるのは抗りンハ球抗体の 中のある populationに限られることを示唆した。

しかし，私共の実験では脳抗原で抗リンパ球抗体 活性が吸収される程度は中枢神経障害の有無で差 がなく，上述の成績を支持し得なかった。いずれ にしても, 抗リンパ球抗体のsubpopulation $と$ SLE の病像との関連性の追求は, 臨床的にも病態解析 上にも大変興味のあるところである。

SLEでは多種類の自己抗体が証明されるため, CNSの発症と結びつけて脳組織に対応する自己 抗体の検索も10年数前からなされている。最近の 研究によ机ば, 抗神経細胞抗体はwarm-reactive IgGクラスのものとcold-reactive IgMクラスとに 分けられ，前者の消長がCNSとよく相関し，リン パ球との間で交皮反応も示さないという。ささら，
このIgG神経細胞抗体活性が髄液中でも証明さ れ，CNS-SLEではその量は血清中より8倍多く 存在し，しかも血清中より㖪液中での活性が中枢 神経障害をよく反映しているといら成績も発表さ れている。このことは本抗体が中枢神経組織内で 産生され，直接神経細胞膜障害している可能性 を示唆している。興味を引く点はリウマチ熱や Huntington舞踏病では抗神経細胞抗体の活性が 主とし尾状核ノイロンに対して見出されているの に対して，SLEのそ㧈は主に脳皮質であったこと である。

しかし，脳抗原と交杈反応を示す抗リンパ球抗 体にしろ，抗神経抗体にしろ，どの上うな機序で blood-brain barrierを通過するのか，また通過後 はどの上うな機序で脳障害するのか，これらが これから解決すべき問題として残されている。

最近, 抗燐脂質抗体之種々の中枢神経障害々の 間に関連性があるといら報告がなされてきた。こ れらの臨床症状性脳虚血あるいは梗塞の結果であ るものが多い。実際に私共の成績（表 3) でも脳 血管障害群では抗燐脂質抗体の陽性率(BFP. STS $42.8 \%$, PTT延長 $57.1 \%$, 抗カルジオリピソ 抗体 $42.9 \%$ ）が有意に高く，上述の考之を支持寸 るものであった。

いずれにしても，CNS-SLEの病像は極めて多 彩であることから、すべてが単一の発症機序で起 こるものとは考えられない。

表 3.中枢神経ループスの病型別模査成績

\begin{tabular}{|c|c|c|c|c|c|c|}
\hline & BFP-STS & $\begin{array}{l}\mathrm{PTT} \\
\text { 延長 }\end{array}$ & 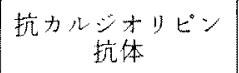 & $\begin{array}{l}\text { Coombs } \\
\text { Test (D) }\end{array}$ & リウマトイド & 抗DNA抗体 \\
\hline 精神症状 & $12.0 \%$ & $13.0 \%$ & $19.2 \%$ & $19.2 \%$ & $19.2 \%$ & $66.7 \%$ \\
\hline 脳血管障害 & $42.8^{*}$ & $57.1^{*}$ & 42.9 & 37.5 & 7.1 & 50.0 \\
\hline 痓䠞 & 20.0 & 35.7 & 20.0 & $46.7^{*}$ & 33.3 & 45.5 \\
\hline 髓膜脳炎 & 0.0 & 50.0 & 0.0 & 0.0 & 25.5 & 50.0 \\
\hline 䯣膜绅 & 0.0 & 0.0 & 33.3 & 33.3 & 0.0 & 33.3 \\
\hline 舞踏病 & 0.0 & 0.0 & ND & 50.0 & 0.0 & 50.0 \\
\hline その他のルーブス & 15.0 & 17.2 & 10.0 & 23.3 & 13.6 & 54.2 \\
\hline
\end{tabular}




\section{4. 診断}

SLE患者に出現する中枢神経障害は，既述の上 うに多種多彩であるが，その原因子(1)原病にも上 つくもの, (2)SLE病変 (尿毒症, 高血王症, 心不 全, 高熱, 代謝障害, 血湤凝固異常など) に続発 寸るもの，(3)感染症(とくに結核菌，真菌，ウ1 ルス)，あるいは(4)薬物（とくにステロイド薬）に 起因するもの，(5)心因反応性精神障害など，多岐 にわたる。

しかも，SLEにもとづく中枢神経障害には臨床 的にも検查所見的にも特異的なものがない。した がって，現時点では中枢神経障害の原因がSLE以 外に求めら机ず，かつその発症直前後に沶いて SLEの活動性を示す所見が同時に存在する場合 にはSLEの中枢神経障害と曑断している。しか し，前述の抗烸脂質抗体陽性例での脳血管障害は 必ずしもSLEの活動期のみに発症しているとは 限らない点で注意が必要である。

日常の臨床でしばしば問題になるのは精神症状 でそのの䄪半数例以上はステロイド菜投与開始以 後に発症をみるため，ステロイド精神病との鑑別 が重要になる。ループス精神病では多かれ少なか れ意識障害が症状形成に関与しているのに対し，

ステロイド精神病の特徵は「感情面の障害」と言 党る。すなわち，少量短期使用例では充実感が高 まり気分が高揚し，多幸的となる。大量長期使用 例では刺激性が増し，精神的緊張と不眠，不快的 方向を示与という。

しかし，症状の灭からの鑑別は一般的には困難 であり，むしろ危険である。日常診療ではSLE患 者が精神症状を呈してきた時には一応ルーブス精 神病として取り扱い, retrospectiveにステロイド 薬に対守る反応態度や精神症状の消長とステロイ ド量の増減との関保をみてから確定診断を下寸こ との方が多いし，その方が間違いも少ない。

CNS-SLEでは種々の検查所見が異常值を示す が，特異的ではなく，診断上は余り役立たない。 しかし，その病態の解析とかその経過を追跡する 上では大変参考になるものがいくつかある。
䯣淮㛟查では，約半数例が異常在示す。とくに 総蛋白量扣上びIgGの增加がよく又ら机, 病状の 改善上並行して减少与る。この傾向は隹䯣や末梢 神経の障害を伴ら時により顕者であり，精神症状 の及の場合は余りみら机ない，頻度は上り少ない が，䯣圧の上昇や細胞増加も観察される。髄液中 のcyclic GMPも上弄するといら。

脳波所見については中枢神経障害の有無に関係 せず, SLEの60\%以上の症例が異常を示す.CNS SLEに限れば，80\%以上の症例で異常脳波が認め ら机る。異常脳波のpatternは一般にびまん性徐波 を主とするが，種々のものが観察される。脳波所 見と中枢神経障害の内容との間には一定の関保は 見出さ机ていない，しかし，中权神経障害の軽快 上注亚行して脳波所見が正常化寸る㑯向は西 る。與味あることは, non CNS-SLEでも異常脳波 を示寸時はSLEの活動期であることが多く，SLE の活動性の消失と並行してやはり脳波所見の改善 がみられる。このことはSLEではかなりの症例で sub-clinicalな中枢神経障害が存在していること を示喛しているのかもしれない，

SLEの脳血管の主たる障害部位が造影不能な 微小血管であるため，脳血管撮影を施行すること は余り意味がない。少しろ，より侵襲性の少な

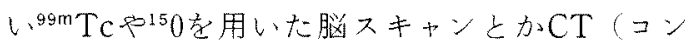
ピューター断層)で释過圭追って施行した方が病 態の解析, 治療効果の判定や予徯の推定の上には 有用性が高いであ万う。最近では, MRI（核磁気共 鳴の方がCT上り感度を含め有用性が高いこと が判明し，日常㟝療ても使执札になりつつある。

\section{5. 治療}

急性期CNS-SLEの治療として現在広く用いら れている力法は、ステロイド薬の大量療法である。 その根拠の一つとして，大量療法を行うように なってから死因としての中枢神経障害が最近減少

していることが挙代られる。

ステロイド投与量の決定はループス腎症と同様 に極めて経験的なものである。症例によってはス テロイド菜を増量せずに，さらには無治療でも中 
枢神経障害が自然に軽快することも確かにある。 かかる場合の中枢神経障害は多くは機能的精神 病、けいれんや舞踏病である。そのためステロイ ド薬の大量療法は益がなく、むしろ重篤な合併症 を誘発し，死因を中枢神経障害から感染症に変克 たに過ぎないといら批判的意見も市る。

CNS-SLEは各病型に上り，その発症形態のみ ならず予後も異なるので，当然治療法も病型別に なされるべきと考えるが，いまだ統一した治療法 がないここでは私共が日常行っているCNS. SLEでの病型別のステロイド薬投与量の目安を 述べて打く。䯣膜炎は $30 \mathrm{mg} /$ 日 (分 3 ), 器質的精 神病已抗燐脂質抗体陰性の脳血管障害注 $60 \mathrm{mg} /$ 日 (分 3 )以上, 痉孪々髄膜脳炎に対しては $100 \mathrm{mg} /$ 日 （分 3－4）以上を投与している．治療に反応しな ければ, 前投与量の $50 \%$ を増量するが, 病状によっ てはパルス療法も併用する、

CNS-SLEに対する免疫抑制薬の効果はいまだ 確立されていないが，最近私共は抗橉脂質抗体陽 性の再発しやすい脳血管障害例にcyclophosphamideの併用を試み，良好な成績を得ているの で，今後多数例の検討が必要であ万5。

\section{おわりに}

SLEの中枢神経障害について、問題点を指摘し
ながら解説した。中枢神経障害に関する研究は腎 障害のそれと比較すると極めて立ら遅れている感 を否めない、しかしながら，臨床免疫学や核医学 などの他領域の学問の進歩につれて，最近10年間 には夥しい数の研究報告がなされており，かつそ の成績にる着実な進歩の跡がうかが充る。consensusが得られている結果は極めて少ないが，現 在の研究状況を省みる之これらの成績が臨床の場 に反映される日もをれ程遠くはないものと期待さ 机る。

\section{文献}

1) Lee P, et al: Systemic lupus erythematosus. A review of 110 cases with reference of nephritis, the nervous system, infections, aseptic necrosis and prognosis. Quart J Med 46:1, 1977

2) Estes D, Christian CL: The natural history of SLE by prospective analysis. Medicine $50: 85$, 1971

3)柏䗁禎夫：全身性エリデートーデスの中枢神経障 害. 皮哃科の臨床 $24: 855,1982$.

4) 岡田 純,他：SLE 治療の現況一SLE の中枢神経 障害。日臨免疫 $12: 567,1989$,

5) Sibbitt WL, et al: Magnetic resonance and computed tomographic imaging in the evaluation of acute neuropsychiatric disease in systemic lupus erythematosus. Ann Rheum Dis 48: 1014, 1989 